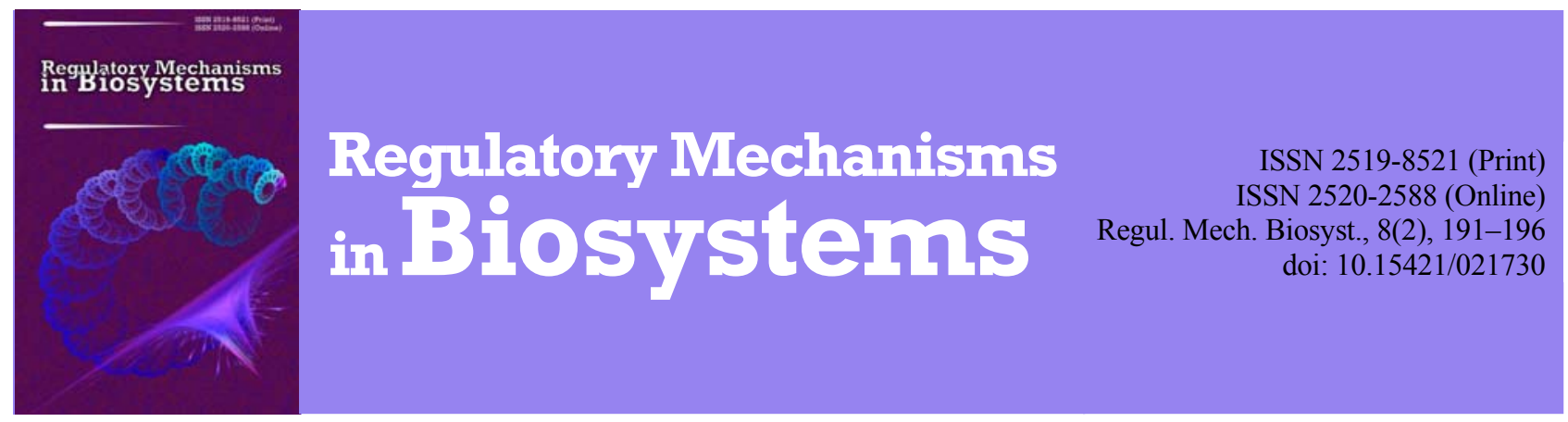

\title{
Biochemical properties of the plasma of rats with the experimentally induced hepatitis after oral administration of sodium diclofenac
}

\author{
V. Gryshchenko \\ National University of Life and Environmental Sciences of Ukraine, Kyiv, Ukraine
}

Article info

Received 24.03.2017

Received in revised form 20.04.2017

Accepted 23.04.2017

National University of Life and Environmental Sciences of Ukraine, Heroyiv Oborony Str. 15, Kyiv, 03041, Ukraine. Tel. $+38-066-910-43-43$

E-mail:viktoriya_004@ukr.net
Gryshchenko, V. (2017). Biochemical properties of the plasma of rats with the experimentally induced hepatitis after oral administration of sodium diclofenac. Regulatory Mechanisms in Biosystems, 8(2), 191-196. doi:10.15421/021730

We conducted an analysis of the metabolic activity of the liver and defined the peculiarities of biochemical parameters and macroelement composition of blood plasma of rats with experimentally induced toxic hepatitis. Hepatopathology was modeled by oral administration of sodium diclofenac at a dose of $12.5 \mathrm{mg} / \mathrm{kg}$ of body mass to rats during 14 days. For the preparation of plasma, rat blood was collected from the abdominal aorta into test-tubes with heparin, and then it was centrifuged at $1500 \mathrm{rev} . / \mathrm{min}$ for $15-20 \mathrm{~min}$. Then we studied biochemical parameters of blood indicators (level of total protein, albumin, total and conjugated bilirubin, glucose, creatinine, urea, triacylglycerols, cholesterol, thymol test value, activities of ALT, AST, LP and GGT, amylase and lipase) and also its macroelement composition: concentration of sodium, potassium, phosphorus, calcium, magnesium and chlorine using automatic biochemical analyzer «BioSystem A15» (Spain) according to the recommendations of the International Federation of Clinical Chemistry (IFCC) Experts Panel. The results of the introduction in the laboratory rats of drug-induced toxic hepatitis indicate a decrease of metabolic activity of hepatocytes under this hepatopathology. The results showed a decrease in total protein by $17 \%$, albumin by $11 \%$, glucose by $6 \%$ triacylglycerols by $53 \%$, cholesterol by $54 \%$, and an appreciable increase in thymol test value (by a factor of 2.8). Besides this, disruption of the liver pigment function, development of cytolytic syndrome and intrahepatic cholestasis were revealed in the affected animals. The increased activity of the studied blood enzymes (ALT by $28 \%$, AST by $45 \%$, LP by $30 \%$, GGT by a factor of 2.1) confirmed these disruptions. The increase in AST/ALT by $12 \%$ ratio confirmed destructive changes in cell membranes, including mitochondrial membranes, caused by metabolic changes under the toxic influence of sodium diclofenac. The increased activities of $\alpha$-amylase by a factor of 2.4 and lipase by a factor of 8.3 indicate complex negative changes in the organism, not only in liver structure, but also in the pancreas. The results of the study indicate hypocalcemia (decrease by $29 \%$ ), hypophosphatemia (decrease by $47 \%$ ) and hypomagnesaemia (decrease by $38 \%$ ) and a simultaneous increase in the $\mathrm{Ca}: \mathrm{P}$ ratio by $35 \%$. The last mentioned changes can cause the development of endogenous osteopathy. The results of the study can be used in diagnostics of development of hepatopathology caused by the toxic effects of medication on the liver, for prevention of complications through the early implementation of effective correction therapy.

Keywords: liver; biochemical parameters; enzymes; macroelements

\section{Біохімічний профіль плазми крові щурів за експериментального гепатиту на тлі введення натрію диклофенаку}

\author{
В. А. Грищенко
}

Національний університет біоресурсів і природокористування Украӥни, Київ, Украӥна

Установлене зниження метаболічної активності печінки та особливості біохімічних показників і макроелементного складу плазми крові лабораторних щурів за експериментального моделювання гепатиту на тлі введення натрію диклофенаку. Це підтверджується зменшенням у плазмі крові концентрації загального протеїну на $17 \%$, альбуміну - на $11 \%$, глюкози - на 6\%, триацилгліцеролів - на $53 \%$ i холестеролу - на 54\%, а також зростанням у 2,8 раза величини тимолової проби порівняно 3 контролем. У хворих тварин діагностовано розлади пігментної функції печінки, розвиток цитолітичного синдрому та внутрішньопечінкового холестазу, що підтверджується підвищенням активності АлАТ на $28 \%$, АсАТ на $45 \%$ та коефіцієнта АсАТ/АлАТ на $12 \%$, ЛФ на $30 \%$ і $\gamma$-ГТП в 2,1 раза порівняно 3 контролем. Гіперензимемія $\alpha$-амілази в 2,4 раза та ліпази у 8,3 раза свідчить про зміни функціонального стану підшлункової залози. Для макроелементного складу плазми крові хворих тварин характерна гіпокальціємія (зменшується на 29\%), гіпофосфатемія (на 47\%) i гіпомагніємія (зменшується на $38 \%$ ) та зростання величини співвідношення Са : Р на $35 \%$ порівняно 3 контролем, що може спровокувати розвиток ендогенної остеопатії. Результати експериментального дослідження важливі для поліпшення діагностики розвитку токсичного гепатиту внаслідок ураження печінки НПЗП, профілактики виникнення ускладнень і призначення ефективної коригувальної терапії.

Ключові слова: печінка; біохімічні показники; ензими; макроелементи 


\section{Вступ}

У печінці як найбільшій травній залозі організму сконцентровані найважливіші фізіолого-біохімічні процеси, необхідні для підтримання гомеостазу організму (Chang and Schiano, 2007; Shapiro and Lewis, 2007). Останніми роками відмічається різке зростання кількості медикаментозних уражень печінки (Bunchorntavakul and Reddy, 2012; Rahmani et al., 2016). До 40\% усіх випадків діагностованого гепатиту зумовлено лікарськими препаратами (Donnelly et al., 2017; Lin et al., 2017). Більша частина не визначених за етіологією гепатитів та цирозів печінки також викликана застосуванням медикаментів. Велике значення для розвитку медикаментозного ураження печінки мають власне гепатопатології: стеато3, печінкова недостатність або холестаз, що сприяють кумуляції лікарських препаратів та їх метаболітів у гепатоцитах, тяжкі захворювання серцево-судинної, респіраторної, ендокринної систем і нирок, які супроводжуються вираженими порушеннями функціонального стану уражених органів (Taleb et al., 2014; Verbeek et al., 2015).

Один із перших проявів ії токсичного ураження - розвиток запальної реакції та жирова дистрофія різного ступеня вираженості (Blas-Garcia et al., 2016). Серед лікарських препаратів, що викликають гепатопатологію, слід відзначити антибіотики, нестероїдні протизапальні препарати, сульфаніламідні засоби, гормональні та інші, які продовжують широко застосовуватися у терапії, деякі з них приймаються роками. Медикаментозні гепатити супроводжуються відповідними синдромами, що спостерігаються при ураженнях печінки: інфільтрацією, дистрофією, холестазом, некрозом (Teschke et al., 2013; Okudo and Anusim, 2016). Їх вираженість залежить від дози ліків, але це буває далеко не завжди. Частіше ураження печінки виникає на тлі лікування декількома гепатотоксичними препаратами або при повторних курсах терапії та залежить від тривалості їх прийому (Chalasani, 2005; Calderon et al., 2010; Bawany et al., 2013; Moole et al., 2015; Okudo and Anusim, 2016).

За гострих і хронічних гепатитів, отруєння гепатотоксичними речовинами відмічається різке зниження біоенергетичного потенціалу хімічних перетворень у гепатоцитах, прогресує індукція вільних радикалів, підвищується інтенсивність пероксидного окиснення ліпідів і активність мембранних фосфоліпаз (Koliaki et al. 2015; Ipsen et al., 2016; Gariani et al., 2017). Це порушує проникність усіх субклітинних структур, знижує електричну міцність мембран, що спричинює деструкцію гепатоцитів (Malhi and Kaufman, 2011). За таких обставин уповільнюються процеси переамінування та дезамінування амінокислот, погіршується їх використання у синтезі білка, складних білкових комплексів та біологічно активних речовин (Calderon et al., 2010). Зазначене негативно позначається на здатності гепатоцитів синтезувати альбумін, фактори згортання крові. Поряд із цим, порушується екскреція кон'югованого білірубіну, естерифікація холестеролу та глюкуронізація багатьох сполук (Moole et al., 2015; Okudo and Anusim, 2016). Водночас це спричиняє порушення детоксикаційної функції печінки (Allen et al., 2011).

Розвиток токсичного гепатиту у тварин викликає зміни інтенсивності та спрямування біохімічних процесів, які безпосередньо пов'язані з обміном мінеральних речовин і корелюють із функціональним станом печінки (Fabbrini and Magkos, 2015). Це свідчить про глибокі порушення метаболізму на клітинному рівні та суттєві розлади структурно-функціонального стану клітинних мембран. Дезорганізація у структурі гепатоцитів і ендотеліоцитів жовчовідвідних шляхів, задіяних у патологічному процесі, негативно позначається на обміні макроелементів, що відображається на інтенсивності стабілізації електролітного та кислотно-основного балансу в організмі тварин, хворих на токсичний гепатит (Baghdasaryan et al., 2016).

У сухому залишку жовчі міститься кальцій, натрій, калій, аніони гідрокарбонату, фосфату, хлору. У свою чергу, жовч сприяє всмоктуванню, поряд 3 амінокислотами, холестеролу, жиророзчинних вітамінів і солей кальцію, що підтверджує регуляторну роль гепатобіліарної системи в обміні мінеральних елементів (Shapiro and Lewis, 2007; Cole et al., 2016). Очевидно, що розвиток запальної реакції та холестазу, характерний для токсичної форми гепатиту, буде відповідним чином відображатися на обміні мінеральних речовин в організмі хворих тварин.

Серед макроелементів особливе місце посідають кальцій, фосфор, магній, калій і натрій, оскільки вони беруть участь у багатьох ланках метаболізму клітин, впливають на проникність їх мембран, задіяні в енергетичних процесах на рівні мітохондрій і в генерації потенціалу дії в м'язових і нервових клітинах, сприяють вивільненню та фізіологічній дії багатьох медіаторів і гормонів, забезпечують передачу збудження вздовж нервовом'язового волокна, підтримують кислотно-основний гомеостаз організму (Koliaki et al., 2015; Verbeek et al., 2015).

Комплексне проведення біохімічних досліджень сприяє визначенню особливостей молекулярних механізмів патогенезу гепатопатології, які тісно пов'язані з розвитком запальних, дистрофічних і дегенеративних змін у паренхімі печінки та характеризують виникнення ускладнень, що вкрай важливо діагностувати на ранніх стадіях розвитку патології. За змінами біохімічних показників крові можна визначати порушення синтетичної та видільної функцій печінки, наявність і ступінь розвитку цитолізу та холестазу (Allen et al., 2011; Minhas et al, 2017) тощо. Тому мета нашого дослідження полягала у з'ясуванні особливостей біохімічних показників плазми крові та ії макроелементного складу, що характеризують метаболічну та функціональну активність печінки, за експериментального токсичного гепатиту на тлі введення натрію диклофенаку.

\section{Матеріал і методи досліджень}

В експеримент залучали білих лабораторних щурів (самців), яких підбирали за принципом аналогів (Vlizlo et al., 2012), із масою тіла 200-220 г. Сформовано дві групи щурів (дослідну та контрольну) по 12 тварин у кожній. Для цього їх окремо поміщали у клітки. До початку експерименту щурів витримували на карантині 3 клінічним обстеженням протягом 14 діб. Тварин утримували на збалансованому раціоні, що містив усі необхідні біологічно активні та поживні речовини. Вони мали вільний доступ до корму та питної води. Проводили моніторинг зміни маси тіла та спожитого дослідними тваринами корму. Тривалість експерименту становила 14 діб.

Упродовж експерименту дотримувалися вимог «Європейської конвенції про захист хребетних тварин, які використовуються для експериментальних і наукових цілей» (Страсбург, 1986), Закону України «Про захист тварин від жорстокого поводження» № 3447 від 21.02.2006 року.

Моделювання токсичного гепатиту в лабораторних щурів здійснювали за авторською розробкою шляхом перорального введення натрію диклофенаку (нестероїдний протизапальний препарат, НПЗП) у дозі 12,5 мг/кг маси тіла тварини протягом 14 діб (Serdyukov et al., 2008; Melnychuk and Gryshchenko, 2016), відповідно до чинних критеріїв стандартизації та якості проведення біологічних експериментів та принципів біомоделювання (Vlizlo et al., 2012). У контрольній групі перебували інтактні тварини.

Більшість НПЗП після всмоктування у шлунково-кишковому тракті надходить до печінки. У гепатоцитах вони зазнають біотрансформації (передусім за дії різних ізоензимів цитохрому P450, 2E1 та 1A2) із подальшим утворенням NAPQI (Gariani et al., 2015; Björnsson and Hoofnagle, 2016). Наступні етапи їх перетворень пов'язують із взаємодією з глутатіоном. При цьому гідрофільні метаболіти, що утворюються, транспортуються мембранозв'язаними білками гепатоцитів у жовч або кров. 3 організму вони видаляються через травний тракт i нирки. Зі зростанням добової дози препарату підвищується вміст NAPQI. У такому разі відмічається дефіцит глутатіону. NAPQI взаємодіє з нуклеофільними групами протеїнів гепато- 
цитів, що спричиняє їх некроз. Індукція або інгібування активності печінкових ензимів за дії ксенобіотиків викликає зростання чи зменшення концентрації останніх у плазмі i, як наслідок, розвиток небажаних реакцій (передусім запалення).

Клінічні ознаки токсичного гепатиту у дослідних щурів оцінювали за комплексом показників: зовнішнім виглядом, поведінкою, апетитом, масою тіла, еластичністю шкіри, станом шерстного покриву, а також проводили огляд і пальпацію черевної стінки, характеризували калові маси згідно із загальноприйнятими методиками, описаними Vlizlo et al. (2012). Стійкі та виражені клінічні ознаки захворювання починали проявлятися у хворих тварин на сьому добу перорального введення натрію диклофенаку та відзначалися пригніченням загального стану, зменшенням рухової активності й апетиту, втратою маси тіла по групі на 10-15 г, скуйовдженням шерстного покриву, частковим зниженням еластичності та сухістю шкіри, підвищенням тонусу стінок живота, кашоподібною консистенцією та різким запахом фекалій із домішками неперетравленого корму та слизу. У таких щурів температура тіла, частота дихання та пульсу відповідали параметрам тварин контрольної групи.

Під час патолого-анатомічного розтину щурів після введення препарату натрію диклофенаку констатовано темновишневий колір, в'ялу консистенцію та кровонаповнення печінки, відмічаються ознаки іiі дистрофії, а в інтактних тварин вона відрізнялася рівномірним червоно-бурим кольором, пружною консистенцією. За гістологічного дослідження зрізів печінки хворих щурів відмічається розширення кровоносних судин та переповнення їх кров'ю, окремі клітини у стані жирової дистрофії (ядра зміщені на периферію клітини, цитоплазма прозора, клітини мають перснеподібну форму), виражений набряк просторів Діссе, спостерігається дискомплексація печінкових балок і лімфоцитарна інфільтрація сполучної тканини. Останнє свідчить про розвиток запальної реакції під час уведення в організм щурів дослідної групи натрію диклофенаку. Процес дискомплексації охоплює окремі ділянки печінкових часточок, гепатоцити розташовані невпорядковано, на малому збільшенні утворюють коміркові структури.

Установлені макроскопічні та гістологічні зміни печінки тварин дослідної групи характеризують розвиток неспецифічного реактивного гепатиту. Домінує у гістоморфологічних змінах паренхіми печінки жирова та зерниста дистрофія, втрата радіальної орієнтації пластинок гепатоцитів і розширення просторів Діссе, повнокрів’я судин. Виходячи з цього, можна припустити, що центролобулярний характер ураження печінки за дії натрію диклофенаку зумовлений перивенозною локалізацією цитохрому $\mathrm{P}_{450}, 2 \mathrm{E} 1$ та інших ензимів, які каталізують утворення токсичного інтермедіату - N-ацетил-пара-бензохіноніміну (Verbeek et al., 2015). Ураження гепатоцитів супроводжується запальною реакцією.

Для отримання плазми кров у щурів відбирали з черевного відділу аорти у пробірки з гепарином, потім центрифугували за 1500 об./хв упродовж 15-20 хв. Далі досліджували біохімічні показники плазми крові (вміст загального протеїну, альбуміну, загального та кон'югованого білірубіну, глюкози, креатиніну, сечовини, триацилгліцеролів, холестеролу, величину тимолової проби, активність аспартат-амінотрансферази (АсАТ), аланін-амінотрансферази (АлАТ), лужної фосфатази (ЛФ), $\gamma$-глутамілтранспептидази ( $\gamma$-ГТП), $\alpha$-амілази та ліпази, а також їі макроелементний склад: концентрацію натрію, калію, фосфору, кальцію, магнію, хлору на біохімічному аналізаторі «BioSystem A15» (Іспанія) відповідно до рекомендацій панелі експертів Міжнародної федерації клінічної хімії (IFCC). Для виконання зазначених досліджень використовували реактиви фірми «BioSystems» (Іспанія).

Обробку результатів здійснювали у пакеті Statistica 6.0 (StatSoft Inc., USA). Вірогідність різниці між вибірками оцінювали за t-критерієм Стьюдента, попередньо перевіривши нормальність їх розподілу. Розбіжності вважали вірогідними за $\mathrm{P}<0,05$.

\section{Результати}

Результати біохімічних, у тому числі ензиматичних, досліджень плазми крові за експериментального токсичного гепатиту щурів наведено в таблицях 1 і 2. Зниження у плазмі крові тварин дослідної групи рівня загального протеїну (на 17\%) на тлі зменшення вмісту альбумінів (на 11\%) підтверджує порушення протеїнсинтезувальної функції печінки та розвиток запальної реакції, що, як відомо (Allen et al., 2011), характерно для цитолітичного синдрому за ураження гепатоцитів. У відповідь на гіпоальбумінемію у плазмі крові хворих тварин відмічене компенсаторне підвищення вмісту протеїнів $\gamma$-глобулінової фракції, що підтверджується позитивними результатами тимолової проби (збільшення ступеня каламутності у 2,8 раза). Як описано нами раніше (Hryschenko, 2011), за токсичного гепатиту також значно пригнічується синтез факторів згортання крові. При цьому не зазнають кількісних змін показники залишкового азоту (креатинін і сечовина), що виключає на етапі їх дослідження наявність нефропатії. У таких хворих зберігається здатність гепатоцитів синтезувати сечовину в орнітиновому циклі, хоча помітна тенденція до зменшення іiі концентрації у плазмі крові.

\section{Таблиця 1}

Біохімічні показники плазми крові щурів в експериментальних умовах $(\mathrm{M} \pm \mathrm{m}, \mathrm{n}=12)$

\begin{tabular}{lcc}
\hline \multicolumn{1}{c}{ Показник } & \multicolumn{2}{c}{ Група } \\
\cline { 2 - 3 } & контрольна & дослідна \\
\hline Загальний протеїн, г/л & $72,9 \pm 3,1$ & $60,3 \pm 3,2^{*}$ \\
Альбумін, г/л & $41,3 \pm 1,6$ & $36,8 \pm 0,7^{*}$ \\
Загальний білірубін, мкмоль/л & $2,9 \pm 0,2$ & $60,5 \pm 3,0^{*}$ \\
Кон'югований білірубін, мкмоль/л & $1,43 \pm 0,24$ & $25,33 \pm 0,81^{*}$ \\
Глюкоза, ммоль/л & $6,40 \pm 0,03$ & $6,05 \pm 0,05^{*}$ \\
Креатинін, мкмоль/л & $68,7 \pm 4,1$ & $55,8 \pm 5,8$ \\
Сечовина, ммоль/л & $6,3 \pm 0,4$ & $5,9 \pm 0,2$ \\
Тимолова проба, S-Н & $0,66 \pm 0,11$ & $1,83 \pm 0,06^{*}$ \\
Триацилгліцероли, ммоль/л & $1,69 \pm 0,27$ & $0,79 \pm 0,15^{*}$ \\
Холестерол, ммоль/л & $3,13 \pm 0,20$ & $1,43 \pm 0,04^{*}$ \\
\hline
\end{tabular}

Примітка: * - різниця відносно щурів контрольної групи за $\mathrm{P}<0,05$.

Водночас зниження у плазмі крові щурів дослідної групи вмісту глюкози (на 6\%) порівняно 3 контролем пояснюється кисневим голодуванням гепатоцитів внаслідок їх набрякання та порушення мікроциркуляції, наступною деструкцією 3 ушкодженням мітохондрій i зниженням інтенсивності процесів окисного фосфорилювання. У свою чергу, енергодефіцит, який при цьому розвивається, - одна 3 причин пригнічення синтезувальної функції печінки.

Для щурів, хворих на токсичний гепатит, характерне явище гіполіпідемії та гіпохолестеролеміі, що відповідно супроводжується зменшенням у плазмі крові вмісту триацилгліцеролів на 56\% і холестеролу на 54\%. Розвиток у тварин дослідної групи гіполіпідемії підтверджує наявність деструктивних змін паренхіми печінки та порушення обміну ліпідів.

У плазмі крові хворих тварин має місце суттєве підвищення вмісту загального білірубіну (у 21 раз) за рахунок кон'югованої фракції (у 18 разів), що вказує на порушення пігментної та жовчовидільної функцій гепатоцитів.

Дані таблиці 2 свідчать про підвищення у плазмі крові хворих щурів активності відносно специфічних для печінки ензимів. Зростає активність АлАТ, АсАТ і ЛФ (відповідно на 28\%, $45 \%$ і 30\%), підвищується величина коефіцієнта АсАТ/АлАТ на $12 \%(\mathrm{P}<0,05)$ порівняно з контролем. Останнє підтверджує наявність у тварин дослідної групи деструктивних змін клітинних оболонок, у тому числі мітохондріальних мембран, за токсичної дії натрію диклофенаку на печінку, а також розвиток біохімічного синдрому гепатоцелюлярної недостатності та внутрішньопечінкового холестазу. Водночас підвищується активність $\gamma$-ГТП у 2,1 раза, амілази - в 2,4 раза, ліпази - у 8,3 раза. Висока активність $\gamma$-ГТП у плазмі крові - ознака гепатотоксичності, а гіперензимемія $\alpha$-амілази та ліпази свідчить про залучення у патологічний процес підшлункової залози. 
Таблиця 2

Активність ензимів плазми крові щурів в експериментальних умовах (од./л, $\mathrm{M} \pm \mathrm{m}, \mathrm{n}=12$ )

\begin{tabular}{lcc}
\hline \multirow{2}{*}{\multicolumn{1}{c}{ Показник }} & \multicolumn{2}{c}{ Група } \\
\cline { 2 - 3 } & контрольна & дослідна \\
\hline АлАТ & $91,5 \pm 6,6$ & $117,3 \pm 7,2^{*}$ \\
АсАТ & $89,2 \pm 4,8$ & $129,4 \pm 5,8^{*}$ \\
АсАТ/АлАТ & $0,98 \pm 0,01$ & $1,10 \pm 0,03^{*}$ \\
$\gamma$-ГТП & $11,3 \pm 0,4$ & $24,1 \pm 0,6^{*}$ \\
ЛФ & $350 \pm 15$ & $456 \pm 16^{*}$ \\
$\alpha$-Амілаза & $1025 \pm 52$ & $2504 \pm 52^{*}$ \\
Ліпаза & $4,00 \pm 0,42$ & $33,00 \pm 2,11^{*}$ \\
\hline
\end{tabular}

Примітка: див. табл. 1.

У плазмі крові щурів дослідної групи встановлено істотне зменшення вмісту кальцію (на 29\%), фосфору (на 47\%) та магнію (на $38 \%$ ), що поряд з одночасним підвищенням величини співвідношення Са : Р на $35 \%$ свідчить про порушення обміну зазначених макроелементів в організмі за розвитку експериментального токсичного гепатиту (табл. 3).

Таблиця 3

Вміст макроелементів у плазмі крові дослідних щурів (ммоль/л, $\mathrm{M} \pm \mathrm{m}, \mathrm{n}=12$ )

\begin{tabular}{lcc}
\hline \multicolumn{1}{c}{ Показник } & \multicolumn{2}{c}{ Група } \\
\cline { 2 - 3 } & контрольна & дослідна \\
\hline Калій $(\mathrm{K})$ & $2,92 \pm 0,39$ & $3,11 \pm 0,35$ \\
Натрій $(\mathrm{Na})$ & $137,9 \pm 5,8$ & $134,0 \pm 7,1$ \\
Магній $(\mathrm{Mg})$ & $1,81 \pm 0,03$ & $1,12 \pm 0,03^{*}$ \\
Хлор $(\mathrm{Cl})$ & $92,5 \pm 8,5$ & $93,4 \pm 6,2$ \\
Кальцій $(\mathrm{Ca})$ & $2,38 \pm 0,14$ & $1,70 \pm 0,10^{*}$ \\
Фосфор (Р) & $12,04 \pm 0,38$ & $6,33 \pm 0,26^{*}$ \\
Співвідношення Сa : & $0,20 \pm 0,01$ & $0,27 \pm 0,01^{*}$ \\
\hline
\end{tabular}

Примітка: див. табл. 1.

\section{Обговорення}

Дефіцитний рівень вказаних елементів, очевидно, є наслідком запально-дистрофічних процесів у паренхімі печінки та явища холестазу, що, як відомо (Baghdasaryan et al., 2016), спричинюе зменшення вмісту глікон'югатів у жовчі та порушення засвоєння двовалентних елементів у тонкому відділі кишечника, передусім кальцію. Водночас, зниження у плазмі крові хворих щурів рівня фосфору, кальцію та магнію - результат порушення регуляторної ролі печінки щодо їх обміну в організмі та функціональних розладів мембранних іонних помп, які взаємопов'язані з індукцією деструктивних змін у гепатоцитах.

Виникнення токсичного гепатиту на грунті застосування токсичної дози натрію диклофенаку може спровокувати розвиток ендогенного рахіту, остеодистрофії та інших нозологічних форм остеопатії, що частково підтверджено зростанням ензиматичної активності ЛФ (табл. 2).

Пероральне введення в організм лабораторних щурів натрію диклофенаку за розробленою нами моделлю викликає запальні та деструктивні зміни у паренхімі печінки, що підтверджується результатами комплексних біохімічних досліджень.

Експериментально відтворена гепатопатологія характеризується зниженням метаболічної та функціональної активності гепатоцитів (рис.), що проявляється гіпопротеїнемією, гіпоальбумінемією, гіпоглікемією, гіполіпідемією, гіпохолестеролемією та підтверджується високими значеннями тимолової проби.

Зміни метаболізму протеїнів у печінці відзначаються, як правило, порушенням переамінування та дезамінування амінокислот із подальшим нагромадженням аміаку та інших токсичних сполук, що зумовлює розвиток відповідних ускладнень (аміак виявляє церебротоксичну дію). Водночас гіпоальбумінемія, яка відмічається у хворих на експериментальний гепатит щурів, - індикатор (Gariani et al., 2015) пригнічення білоксинтезувальної функції печінки, причиною виникнення якого може бути енергодефіцит. Останнє узгоджується з розвитком гіпоглікемії у хворих тварин. У такому разі знижується інтенсивність окисних процесів, зростає роль анаеробного гліколізу, що супроводжується надмірним утворенням недоокиснених продуктів метаболізму (лактату та пірувату). Внаслідок цього порушується електролітний і кислотно-основний баланс в організмі хворих на гепатопатологію тварин (Canto et al., 2015).

За таких метаболічних зрушень відбувається руйнування лізосом, звільнення у цитозоль гідролітичних ензимів, що обертається аутолізом і загибеллю клітин (Fabbrini and Magkos, 2015). Прогресуюче зменшення вмісту альбумінів у крові здатне спричинити зниження онкотичного тиску ії плазми, подальший розвиток набряків, а згодом і асцит. Як наслідок, у таких хворих відмічається компенсаторне підвищення вмісту протеїнів $\gamma$-глобулінової фракції (збільшення значень тимолової проби), до яких, передусім (Ilan, 2016) належать імуноглобуліни - захисні протеїни, фактори гуморальної ланки імунітету.

Розвиток гіполіпідеміі та гіпохолестеролемії за токсичного гепатиту щурів доводить наявність деструктивних змін паренхіми печінки та характеризує порушення обміну ліпідів та синтетичної активності гепатоцитів. У гепатоцитах синтезується близько $80 \%$ холестеролу організму та забезпечується його естерифікація, трансформація в жовчні кислоти, відбувається утворення ліпопротеїдів різної щільності (передусім, низької та дуже низької щільності). Це - прояв регуляторної ролі печінки в метаболізмі ліпідів (Bhardwaj and Chalasani, 2007; Guo et al., 2011; Gooijert et al., 2014).

Моделювання у лабораторних тварин медикаментозної форми токсичного гепатиту із застосуванням натрію диклофенаку супроводжується порушенням пігментної функції печінки. Гіпербілірубінемія (підвищення вмісту загального білірубіну в 21 раз) і посилення інтенсивності процесів кон'югації у печінці (збільшення концентрації кон'югованого білірубіну у 18 разів) - прояви іiі компенсаторної реакції, спрямованої на зменшення токсичного впливу некон'югованого білірубіну на організм хворих тварин, що попереджас виникнення білірубінової енцефалопатії (Allen et al., 2011; Baghdasaryan et al., 2016).

Для хворих тварин характерний розвиток гепатоцелюлярної недостатності, цитолітичного синдрому та біліарної обструкції, що підтверджується гіперензимемією АлАТ, АсАТ, ЛФ i $\gamma$-ГТП. У свою чергу, зростання коефіцієнта АсАТ/АлАТ на $12 \%$ доводить наявність уражень внутрішньоклітинних мембран органел (передусім мітохондрій), що пояснюе виникнення порушень енергетичної, синтетичної, регуляторної та інших функцій травної залози за токсичної дії натрію диклофенаку.

Встановлені факти доповнюють дані літератури про те, що визначення активності амінотрансфераз - досить чутливий та інформативний тест щодо змін проникності клітинних мембран гепатоцитів під час ураження печінки екзо- чи ендогенними токсинами (Morita et al., 2009; Saba et al., 2010; Vyshtakaliuk et al., 2015). Одночасне дослідження у плазмі крові активності $\gamma$-ГТП, амінотрансфераз і ЛФ має велике діагностичне значення за комплексного ураження гепатобіліарної системи. У свою чергу, $\gamma$-ГТП чутливіша до виникнення структурно-функціональних порушень у клітинах печінки, ніж АсАТ, АлАТ і ЛФ. Таким чином, активність $\gamma$-ГТП належить до важливих ознак гепатотоксичності і $\epsilon$ позитивною у $90 \%$ випадках захворювань печінки (Gariani et al., 2015; Verbeek et al., 2015).

Істотне зростання у плазмі крові хворих тварин активності $\alpha$-амілази та ліпази (відповідно в 2,4 і 8,3 раза) свідчить про залучення у патологічний процес підшлункової залози, а, отже, розвиток ускладнення експериментальної гепатопатології.

Водночас серед установлених закономірностей у хворих тварин слід відзначити гіпокальціємію, гіпофосфатемію та гіпомагніємію за одночасного зростання співвідношення Са : Р (на 35\%), що свідчить про якісні зміни гідроксиапатиту кісткової тканини. Дефіцитний рівень у плазмі крові таких щурів кальцію, фосфору та магнію можна пояснити розвитком запально-дистрофічних змін у паренхімі печінки та внутрішньо- 
печінкового холестазу, а також вторинним виникненням гострих розладів травлення на тлі токсичної форми гепатопатологіï. У подальшому це може спричинити зниження інтенсивності кісткового метаболізму та формування схильності до резорбційних процесів. Таким чином, патологія печінки у вигляді медикаментозної форми токсичного гепатиту може спрово- кувати порушення процесів осифікації та розвиток ендогенного рахіту, остеодистрофії та інших нозологічних форм остеопатії, що частково вже підтверджено зростанням ферментативної активності ЛФ на $30 \%$ (табл. 2), яке може бути наслідком не лише розвитку внутрішньопечінкового холестазу, а й підвищення активності кісткового ізоензиму.

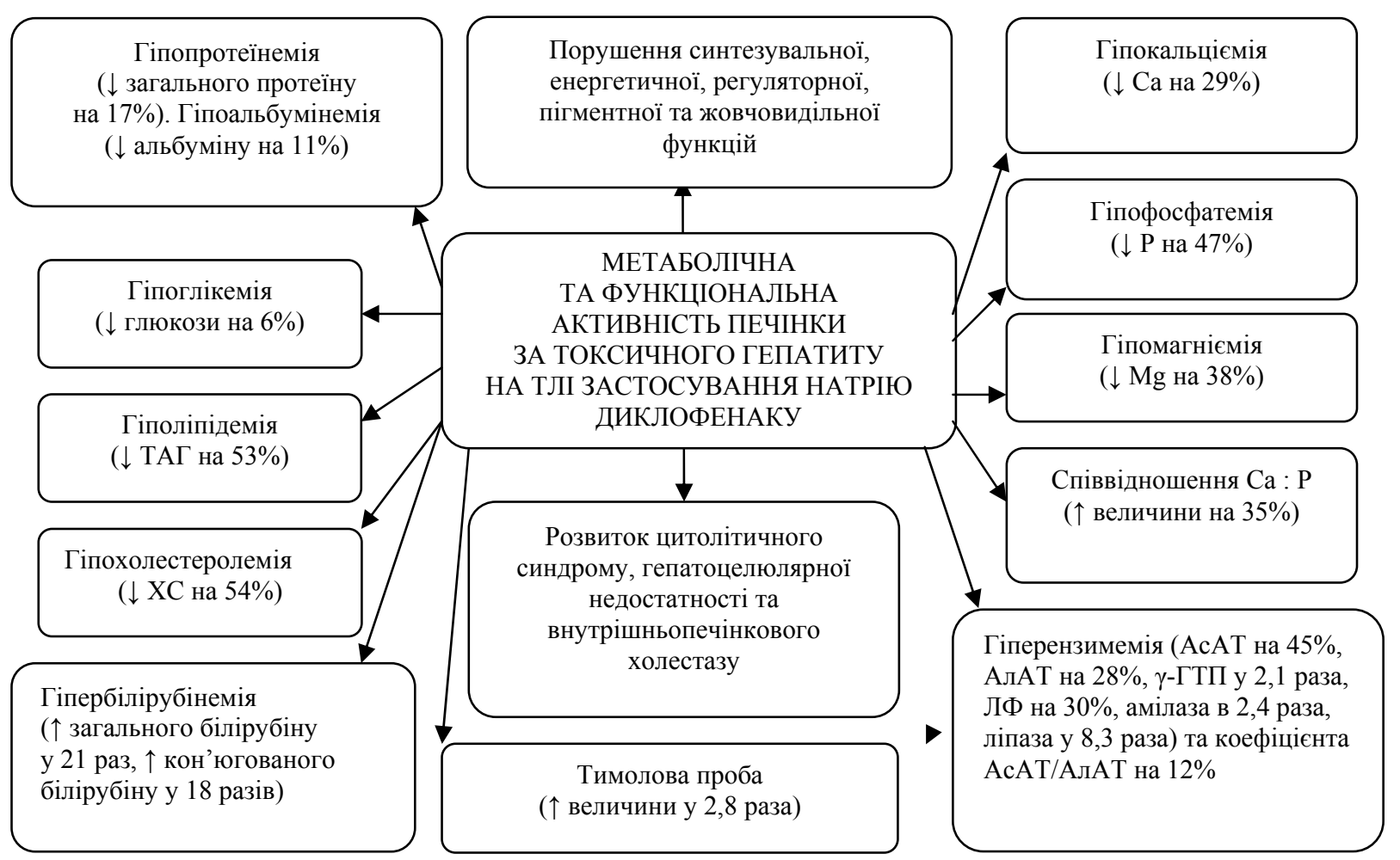

Рис. Особливості метаболічної та функціональної активності печінки за токсичного гепатиту на тлі введення натрію диклофенаку

Фізіологічна роль двовалентних катіонів винятково важлива для повноцінного перебігу багатьох внутрішньоклітинних процесів. Збіднення тканин і органів на зазначені вище макроелементи негативно позначається на внутрішньоклітинному метаболізмі, особливо протеїнсинтезувальній функції гепатоцитів (Hryschenko et al., 2011; Blas-Garcia et al., 2016), що відмічається у випадку експериментального гепатиту. При цьому виникає зростання градієнта концентрації $\mathrm{H}^{+}$на плазматичній мембрані клітин, яке істотно впливає на функціональну активність іонних помп, а, отже, інтенсивність і напрям трансмембранних та біохімічних процесів (Cole et al., 2016). Регуляторна роль печінки у підтриманні кислотно-лужного балансу в організмі ссавців полягає у тому, що в гепатоцитах відбувається остаточна утилізація недоокиснених продуктів проміжних етапів метаболізму протеїнів, ліпідів і вуглеводів (Canto et al., 2015). А тому за патології печінки можливе надлишкове утворення кислих метаболітів (передусім, лактату, пірувату, кетонових тіл) та відповідний розвиток ацидемії. Як наслідок розвивається енергодефіцит, що певною мірою пояснює формування у хворих щурів гіпоглікемії.

\section{Висновки}

У результаті комплексного аналізу біохімічних показників і макроелементного складу плазми крові щурів за експериментального токсичного гепатиту на тлі перорального введення в їх організм натрію диклофенаку встановлено порушення функціонального стану печінки та біліарної системи. Передусім це проявляється розладами метаболічної активності та відповідними змінами синтезувальної, енергетичної, регуляторної, пігментної та жовчовидільної функцій. При цьому виражених змін зазнають такі біохімічні показники плазми крові як уміст загального протеїну (зменшується на 17\%), альбуміну (змен- шується на 11\%), загального та кон'югованого білірубіну (відповідно зростає у 21 і 18 разів), триацилгліцеролів і холестеролу (відповідно зменшується на 53\% і 54\%), активність АсАТ (зростає на 45\%), АлАТ (підвищується на 28\%), величина коефіцієнта АсАТ/АлАТ (збільшується на 12\%), $\gamma$-ГТП (зростає у 2,1 раза) і ЛФ (збільшується на 30\%). Водночас гіперензимемія $\alpha$-амілази в 2,4 раза та ліпази у 8,3 раза свідчить про комплексний характер патології із залученням у патологічний процес підшлункової залози.

У хворих тварин відмічається зменшення в плазмі крові концентрації кальцію, фосфору, магнію (відповідно на 29\%, 47\% і 38\%) та співвідношення Са : Р (підвищується на 35\%) порівняно 3 контролем. Дефіцит в організмі хворих зазначених макроелементів, ймовірно, пов'язаний із порушенням їх засвоєння на рівні травного каналу, транзиторними втратами через вторинні розлади травлення, що супроводжують цю патологію, виснаженням депо організму на ці елементи, змінами регуляторної ролі печінки, а також функціональними розладами мембранних іонних помп. Вочевидь, патологія печінки у вигляді медикаментозної форми токсичного гепатиту може спровокувати розвиток ендогенного рахіту, остеодистрофії та інших нозологічних форм остеопатії, що частково вже підтверджено зростанням ензиматичної активності ЛФ.

Комплексне дослідження біохімічних показників плазми крові дозволило визначити особливості метаболічних зрушень на тлі застосування токсичних доз натрію диклофенаку, що характерно і для інших НПЗП, та своєчасно діагностувати патологію печінки внаслідок іï медикаментозного ураження, що важливо у призначенні ефективної терапії.

На перспективу планується приділити увагу особливостям змін метаболічної активності печінки, взаємопов'язаних із розвитком репаративних процесів за гепатопатології та у випадку застосування засобів клітинної терапії. 


\section{References}

Allen, K., Jaeschke, H., \& Copple, B. L. (2011). Bile acids induce inflammatory genes in hepatocytes: A novel mechanism of inflammation during obstructive cholestasis. American Journal of Pathology, 178(1), 175-186.

Baghdasaryan, A., Fuchs, C. D., Osterreicher, C. H., Lemberger, U. J., Halilbasic, E., Pahlman, I., Graffner, H., Krones, E., Fickert, P., Wahlström, A., Stahlman, M., Paumgartner, G., Marschall, H.-U., \& Trauner, M. (2016). Inhibition of intestinal bile acid absorption improves cholestatic liver and bile duct injury in a mouse model of sclerosing cholangitis. Journal of Hepatology, 64(3), 674-681.

Bawany, M. Z., Bhutto, B., Youssef, W. I., Nawras, A., \& Sodeman, T. (2013). Acute liver failure: an uncommon complication of commonly used medication. American Journal of Therapeutics, 20(5), 566-568.

Bhardwaj, S., \& Chalasani, N. (2007). Lipid lowering agents that cause drug-induced hepatotoxicity. Clinics in Liver Disease, 11(3), 597-613.

Björnsson, E. S., \& Hoofnagle, J. H. (2016). Categorization of drugs implicated in causing liver injury: Critical assessment based on published case reports. Hepatology, 63(2), 590-603.

Blas-Garcia, A., Apostolova, N., Valls-Belles, V., \& Esplugues, J. V. (2016) Endoplasmic reticulum and mitochondria: Independent roles and crosstalk in fatty liver diseases and hepatic inflammation. Current Pharmaceutical Design, 22(18), 2607-2618.

Bunchorntavakul, C., \& Reddy, K. R. (2012). Review article: Herbal and dietary supplement hepatotoxicity. Alimentary Pharmacology and Therapeutics, 37(1), 3-17.

Calderon, R. M., Cubeddu, L. X., Goldberg, R. B., \& Schiff, E. R. (2010) Statins in the treatment of dyslipidemia in the presence of elevated liver aminotransferase levels: A therapeutic dilemma. Mayo Clinic Proceedings, 85, 349-356.

Canto, C., Menzies, K. J., \& Auwerx, J. (2015). NAD(+) metabolism and the control of energy homeostasis: A balancing act between mitochondria and the nucleus. Cell Metabolism, 22, 31-53.

Chalasani, N. (2005). Statins and hepatotoxicity: Focus on patients with fatty liver. Hepatology, 41(4), 690-695.

Chang, C. Y., \& Schiano, T. D. (2007). Drug hepatotoxicity. Alimentary Pharmacology and Therapeutics, 25, 1135-1151.

Cole, H. L., Pennycook, S., \& Hayes, P. C. (2016). The impact of proton pump inhibitor therapy on patients with liver disease. Alimentary Pharmacology and Therapeutics, 44(11-12), 1213-1223.

Donnelly, M. C., Davidson, J. S., Martin, K., Baird, A., Hayes, P. C., \& Simpson, K. J. (2017). Acute liver failure in Scotland: Changes in aetiology and outcomes over time (the Scottish Look-Back Study). Alimentary Pharmacology and Therapeutics, 45(6), 833-843.

Fabbrini, E., \& Magkos, F. (2015). Hepatic steatosis as a marker of metabolic dysfunction. Nutrients, 7(6), 4995-5019.

Gariani, K., Menzies, K. J., Ryu, D., Wegner, C. J., Wang, X., Ropelle, E. R., Moullan, N., Zhang, H., Perino, A., Lemos, V., Kim, B., Park, Y.-K., Piersigilli, A., Pham, T. X., Yang, Y., Ku, C. S., Koo, S. I., Fomitchova, A. Cantó, C., Schoonjans, K. A., Sauve, A., Lee, J.-Y., \& Auwerx, J. (2015). Eliciting the mitochondrial unfolded protein response via NAD repletion reverses fatty liver disease. Hepatology, 63(4), 1190-1204.

Gariani, K., Ryu, D., Menzies, K. J., Yi, H.-S., Stein, S., Zhang, H., Perino, A., Lemos, V., Katsyuba, E., Jha, P., Vijgen, S., Rubbia-Brandt, L., Kim, Y. K., Kim, J. T., Kim, K. S., Shong, M., Schoonjans, K., \& Auwerx, J. (2017). Inhibiting poly ADP-ribosylation increases fatty acid oxidation and protects against fatty liver disease. Journal of Hepatology, 66(1), 132-141.

Gooijert, K. E., Havinga, R., Wolters, H., Wang, R., Ling, V., Tazuma, S., \& Verkade, H. J. (2014). The mechanism of increased biliary lipid secretion in mice with genetic inactivation of bile salt export pump. AJP Gastrointestinal and Liver Physiology, 308(5), 450-457.

Guo, Z., Liu, X. M., Zhang, Q. X., Shen, Z., Tian, F. W., Zhang, H., Sun, Z. H., Zhang, H. P., \& Chen, W. (2011). Influence of consumption of probiotics on the plasma lipid profile: A meta-analysis of randomised controlled trials. Nutrition, Metabolism and Cardiovascular Diseases, 21(11), 844-850.

Hryschenko, V. A., Tomchuk, V. A., Lytvynenko, O. N., Chernyshenko, V. O., Gryschuk, V. I., \& Platonova, T. M. (2011). Otsinka proteyinsintezuyuchoyi funktsiyi pechinki za eksperimentalnogo gepatitu [An estimate of protein synthesis in liver under induced hepatitis]. Ukrainian Biochemistry Journal, 83(1), 63-68 (in Ukrainian)
Ilan, Y. (2016). Novel methods for the treatment of non-alcoholic steatohepatitis targeting the gut immune system to decrease the systemic inflammatory response without immune suppression. Alimentary Pharmacology and Therapeutics, 44(11-12), 1152-1167.

Ipsen, D. H., Tveden-Nyborg, P., \& Lykkesfeldt, J. (2016). Normal weight dyslipidemia: Is it all about the liver? Obesity, 24(3), 556-567.

Koliaki, C., Szendroedi, J., Kaul, K., Jelenik, T., Nowotny, P., Jankowiak, F., Herder, C., Carstensen, M., Krausch, M., Knoefel, W. T., \& Schlensak, M. R. (2015). Adaptation of hepatic mitochondrial function in humans with non-alcoholic fatty liver is lost in steatohepatitis. Cell Metabolism, 21(5), 739-746

Lin, S. C., Heba, E., Bettencourt, R., Lin, G. Y., Valasek, M. A., Lunde, O. Hamilton, G., Sirlin, C. B., \& Loomba, R. (2017). Assessment of treatment response in non-alcoholic steatohepatitis using advanced magnetic resonance imaging. Alimentary Pharmacology and Therapeutics, 45(6), 844-854.

Malhi, H., \& Kaufman, R. J. (2011). Endoplasmic reticulum stress in liver disease. Journal of Hepatology, 54(4). 795-809.

Melnychuk, D. O., \& Gryshchenko, V. A. (2016). Sposib modelyuvannya toksichnogo gepatitu [Method modeling of toxic hepatitis]. Patent UA 105657, 2016 (in Ukrainian)

Minhas, A. M., Usman, M. S., Khan, M. S., Fatima, K., Mangi, M. A., \& Illovsky, M. A. (2017). Link between non-alcoholic fatty liver disease and atrial fibrillation: A systematic review and meta-analysis. Cureus, 9(4), e1142.

Moole, H., Ahmed, Z., Saxena, N., Puli, S. R., \& Dhillon, S. (2015). Oral clindamycin causing acute cholestatic hepatitis without ductopenia: A brief review of idiosyncratic drug-induced liver injury and a case report. Journal of Community Hospital Internal Medicine Perspective, 5(4), 1-5.

Morita, M., Akai, S., Hosomi, H., Tsuneyama, K., Nakajima, M., \& Yokoi, T. (2009). Drug-induced hepato-toxicity test using gamma-glutamylcysteine synthetase knockdown rat. Toxicology Letters, 189(2), 159-165.

Okudo, J., \& Anusim, N. (2016). Hepatotoxicity due to clindamycin in combination with acetaminophen in a 62-year-old african american female: A case report and review of the literature. Case Reports in Hepatology, 2016, 1-5.

Rahmani, S., Asgary, S., Askari, G., Keshvari, M., Hatamipou, M., Feizi, A., \& Sahebkar, A. (2016). Treatment of non-alcoholic fatty liver disease with curcumin: A randomized placebo-controlled trial. Phytotherapy Research, 30(9), 1540-1548.

Saba, A. B., Oyagbemi, A. A., \& Azeez, O. I. (2010). Amelioration of carbon tetrachloride-induced hepatotoxicity and haemotoxicity by aqueous leaf extract of Cnidoscolus aconitifolius in rats. Nigerian Journal of Physiological Sciences, 25, 130-147.

Serdyukov, Y. K., Lytvynenko, O. N., \& Gryshchenko, V. A. (2008). Patologo-anatomichni ta gistologichni zmini v pechintsi shchuriv za medikamentoznogo gepatitu [Pathologo anatomical and histological changes are in liver of rats with drug induced hepatitis]. Suchasn Problemi Toksikologiyi, (2), 63-65 (in Ukrainian).

Shapiro, M. A., \& Lewis, J. H. (2007). Causality assessment of drug-induced hepatotoxicity: Promises and pitfalls. Clinics in Liver Disease, 11(3), 477-505.

Taleb, M., Almasri, I., Siam, N., Najim, A., \& Ahmed, A. (2014). The effect of atorvastatin on liver function among patients with coronary heart disease in Gaza Strip. Pharmacology and Pharmacy, 5(8), 781-788.

Teschke, R., Schulze, J., Schwarzenboeck, A., \& Frenzel, C. (2013). Herbal hepatotoxicity: Suspected cases assessed for alternative causes. European Journal of Gastroenterology and Hepatology, 25(9), 1093-1098.

Verbeek, J., Lannoo, M., Pirinen, E., Ryu, D., Spincemaille, P., Vander Elst, I., Windmolders, P., Thevissen, K., Cammue, B. P. A., Van Pelt, J., Fransis, S. Van Eyken, P., Groote, C. C.-D., Van Veldhoven, P. P., Bedossa, P., Nevens, F., Auwerx, J., \& Cassiman, D. (2015). Roux-en-y gastric bypass attenuates hepatic mitochondrial dysfunction in mice with non-alcoholic steatohepatitis. Gut, 64(4), 673-683.

Vlizlo, V. V., Fedoruk, R. S., \& Ratych, I. B. (2012). Laboratorni metody doslidzhen u biolohiyi, tvarynnytstvi ta veterynarniy medytsyni [Laboratory methods of investigation in biology, stock-breeding and veterinary]. Spolom, Lviv (in Ukrainian)

Vyshtakaliuk, A. B., Nazarov, N. G., Porfiriev, A. G., Zueva, I. V., Minnechanova, O. A., Mayatina, O. V., Reznik, V. S., Zobov, V. V., \& Nicolskyi, E. E. (2015). The influence of the Xymedon preparation (Hydroxyethyldimethyldihydropyrimidine) on the rat liver recovery under toxic damage induced by carbon tetrachloride. Biochemistry, Biophysics and Molecular Biology, 462(1), 143-146. 